\title{
ESTRATÉGIAS DE PERSUASÃO E ESTRUTURAÇÃO DO DISCURSO
}

Afrânio da Silva Garcia (UERJ)

Resumo: Esse artigo pretende mostrar as estratégias de persuasão mais comuns e de que maneira elas servem para estruturar o discurso social e político brasileiro. Dividimos tais estratégias em dois grupos: estratégias de persuasão simples, como a substituição de nomes, o apelo à inclusão, o temor da exclusão, o apelo à autoridade, a modalização do discurso e o emprego de estereótipos; e estratégias de persuasão complexas, como o distanciamento do discurso, a elaboração de mitos, a criação de inimigos, a qualificação excludente, o falso debate, a inintelegibilidade aclamada, o deslocamento tópico e a guerra assimétrica. Todas as seções do trabalho serão fartamente ilustradas com exemplos tirados da publicidade e da propaganda política e ideológica, além de ocasionais menções de acontecimentos reais e de obras de arte.

Palavras-chave: Persuasão; Discurso; Estratégias; Publicidade; Propaganda.

Abstract: This article aims to show the more common strategies of persuasion and in which way they serve do structure the social and political Brazilian speech. We divided such strategies in two groups: simple persuasion strategies, comprising the substitution of names, the appeal to inclusion, the fear of exclusion, the appeal to authority, the modalization of the speech and the use of stereotypes; and complex persuasion strategies, like the distantness of speech, the elaboration of myths, the creation of enemies, the excluding qualification, the fake debate, the acclaimed unintelligibility, the topical displacement and the asymmetric war. All sections of our work will be widely illustrated with examples taken from advertisement and political and ideological propaganda, besides occasional mentions to real events and art works. Keywords: Persuasion; Speech; Strategies; Advertisement; Propaganda. 


\section{INTRODUÇÃO}

O presente trabalho tem por objetivo apresentar as estratégias de persuasão mais empregadas no contexto social e político brasileiro e sua importância na estruturação do discurso.

Trataremos desde as estratégias de persuasão mais simples, como a escolha ou substituição dos nomes, o apelo à inclusão, o temor da exclusão, o apelo à autoridade a modalização do discurso e o emprego de estereótipos, até as mais complexas, como a transparência, o distanciamento do discurso, a elaboração de mitos, a criação de inimigos, a qualificação excludente, o falso debate, a inintelegibilidade aclamada, o deslocamento tópico, etc. Concomitantemente, apresentaremos exemplos de discursos e elementos de propaganda que utilizam as estratégias acima descritas.

\section{ESTRATÉGIAS DE PERSUASÃO SIMPLES}

As estratégias mais simples de persuasão, que ocorrem praticamente em todos os ambientes sociais e em todas as modalidades de comunicação, são:

a) Substituição de nomes ou formas de denominação consiste na escolha intencional do nome ou denominação que melhor se adeque aos nossos propósitos. Por exemplo, ao referir-se aos Estados Unidos, tanto podemos usar o próprio 
nome do país, Estados Unidos (neutro), como a grande nação americana (com carga positiva) ou o Império (com forte carga negativa). Desta forma, toda vez que nos referirmos a essa nação estaremos, implicitamente, reiterando no ouvinte uma avaliação neutra, positiva ou negativa a respeito dela. $\mathrm{O}$ mesmo sucederia com as expressões Leste Europeu (neutra) ou Cortina de Ferro (negativa); americanos (neutra), ianques (negativa) ou nossos irmãos do norte (positiva); Bolsonaro (neutra), Ele Não ou O Fascista (negativa), Mito ou O Capitão (positiva), etc.

b) Apelo à inclusão - extremamente frequente na publicidade, consiste em enfatizar o fato de que o receptor, ao adquirir o produto anunciado ou adotar o comportamento pretendido pelo emissor, terá garantida sua inclusão num grupo social ou numa situação de prestígio. Exemplos dessa estratégia encontram-se em:

- Anúncios de roupas e acessórios femininos, em que se veicula implicitamente ou não que a aquisição de um determinado produto permitirá ao seu possuidor incluir-se num determinado grupo de prestígio: das pessoas elegantes, das pessoas ricas, das pessoas atraentes, etc.

- Anúncios de carros, em que implicitamente se afirma que o possuidor do carro conseguirá 
ser aceito por mulheres bonitas, ter uma vida de "glamour", ingressar na classe dominante, levar uma vida mais aventurosa, etc.

- Anúncios de cigarros, em que se vincula o hábito pernicioso de fumar a uma vida máscula, cheia de aventuras e conquistas, com mulheres bonitas sempre disponíveis, esportes, etc.

c) Temor à exclusão - numa abordagem inversa do apelo à inclusão, afirma-se implicitamente ou não que o fato de o receptor não adquirir determinado produto ou adotar determinado comportamento ou ideologia fará com que ele seja excluído do grupo social ou situação de prestígio. Exemplos comuns de publicidade ou propaganda baseadas no temor à exclusão ocorrem em:

- Anúncios de datas comemorativas - em que se afirma, implicitamente ou não, que o fato de você não dar um presente (de Natal, Dia das Mães, Dia dos Namorados, etc.) excluirá você do grupo das pessoas boas, que se importam com suas mães, namorados, parentes, etc., que se comportam como se espera que um filho, namorado, parente, etc. se comportaria, tornando-o automaticamente num filho ingrato, num namorado sem carinho, num parente omisso, etc. 
- Propaganda de "produtos" e abordagens intelectuais e científicos - em que fica dito, implícita ou claramente, que a não-adoção de uma determinada ideologia ou postura intelectual ou científica, tal como o construtivismo, a neurolinguística, a "nova retórica", etc., implicará na sua exclusão da elite dos intelectuais e cientistas, transformando-o num pensador medíocre, ultrapassado, pouco esforçado, preconceituoso, etc.

- Propaganda política e partidária - na qual se afirma de maneira mais ou menos implícita que o fato de alguém não adotar determinada postura ou ideologia política, como a obsessão antiamericana, o populismo inclusivista, o assistencialismo suicida, o comunismo, transformará automaticamente esta pessoa num fascista, num inimigo do povo, num explorador capitalista, etc.

Obs.: muitas vezes, os anúncios e a propaganda que utilizam a estratégia de temor à exclusão valem-se igualmente do apelo à inclusão, numa postura ambivalente, do tipo: "se você comprar determinado produto ou adotar determinada ideologia ou postura, você terá a felicidade de 
ser incluído num grupo ou situação de prestígio; se não, você será fatalmente excluído deste grupo ou situação. Muitos anúncios de produtos estéticos e artigos de luxo valem-se dessa duplicidade estratégica, apelo à inclusão e temor à exclusão, para alcançarem seus objetivos.

d) Apelo à autoridade - uma das maneiras mais simples e eficazes de aumentar a força persuasiva de uma mensagem é associá-la a algum especialista da área ou a algum expoente da sociedade, dando a essa mensagem o aval de uma figura de autoridade virtualmente inquestionável. Se o especialista no assunto, ou se uma pessoa importante, prestigiada, valorizada pela sociedade confirma sua mensagem, isso atesta sua "veracidade" (ao menos, em termos persuasivos), como podemos constatar pelos exemplos abaixo:

- Anúncios com médicos falando de remédios para o receptor, o fato de um médico famoso, ou de um ator incorporando a figura de um médico famoso, recomendar um determinado remédio reforça a ideia de que aquele remédio é bom;

- Anúncios com jogadores de futebol - para a camada mais popular, um jogador de futebol é uma pessoa que merece toda consideração, o que faz com que o suplemento vitamínico, 
o banco, a cerveja, etc., por eles recomendados sejam imediatamente vistos como produtos de qualidade;

- Anúncios com artista de cinema e televisão - a supervalorização de quem aparece na mídia, principalmente na televisão e no cinema, ainda mais aqueles que lideram as audiências, faz com que produtos e ideias associados ou defendidos por eles sejam logo aceitos pelo público.

e) Modalização do discurso - consiste em arranjar o discurso de tal maneira que ele não sirva a nenhum outro propósito senão o convencimento, a persuasão do ouvinte, não admitindo qualquer questionamento, resposta, sentido figurado, etc. Para tanto, são utilizados a diretividade (o falante diz claramente ao ouvinte o que fazer), a assertividade (o falante sequer aventa a possibilidade de dúvidas ou de negativas), a repetição (veicula-se várias vezes a mesma mensagem) e a paráfrase (uma mensagem dita de uma forma é parafraseada de outra forma, de outra, e de outra). Exemplos desse tipo de estratégia são aqueles anúncios quilométricos, que ficam repetindo sem parar, de várias formas, a mesma proposta, como os anúncios das facas Ginzo, de aparelhos de ginástica, de telessexo ou tele-encontro, etc., além de anúncios centrados num único 
bordão, como Experimenta!, Compre Batom!, Não esqueça da minha Caloi!, etc.

f) Emprego de estereótipos - em termos de persuasão, é muito comum a utilização de estereótipos (formulações generalizantes, fantasiosas e geralmente preconceituosas da realidade) para alcançar os objetivos. Como exemplos de utilização de estereótipos na publicidade e na propaganda, temos os seguintes:

- Anúncios de produtos alimentícios costumam apresentar uma cena familiar estereotipada, em que pai, mãe e filhos se reúnem em volta da mesa para um café da manhã ou almoço idealizado, com todos comendo juntos, em perfeita comunhão e alegria, o que não é confirmado em absoluto pela realidade, visto que a maioria das famílias modernas não compartilha suas refeições, quer porque têm horários desencontrados, quer porque pai e mãe não moram mais juntos, quer ainda porque crianças e jovens pouco se importam com refeições em família;

- Propagandas políticas abordando a educação pública, em que as escolas são sempre excelentes: dotadas de uma entrada acolhedora e atraente, com salas arejadas, iluminadas e amplas; com 
profusão de material didático; e professores e alunos satisfeitos interessados e satisfeitos, o que não corresponde absolutamente à realidade de penúria e exclusão da maior parte das escolas públicas, com vagabundos permanentemente às suas portas desconjuntadas; salas inadequadas e opressivas, muitas vezes com móveis quebrados e lixo amontoado; ausência quase absoluta de materiais didáticos; professores desmotivados e mal vestidos e alunos desinteressados, muitas vezes apáticos ou agressivos.

- Anúncios de sites de encontros, em que a juventude é representada como tudo de bom: alegre, ativa, sem preconceitos, bonita e profundamente simpática e receptiva, inclusive com estranhos ao grupo, o que contraria praticamente tudo que observamos quando entramos em contato com os jovens reais, com seus problemas reais: muitos são deprimidos ou angustiados, a inércia é uma característica bastante comum, muitos têm preconceitos; muitos jovens são feios, mal vestidos, pouco higiênicos; e não são nem um pouco simpáticos nem receptivos com pessoas estranhas ao grupo, excluindo-as sumariamente. 


\section{ESTRATÉGIAS DE PERSUASÃO COMPLEXAS}

a) Transparência - como o discurso autoritário não pressupõe nem permite a resposta do receptor, ele também não lhe permite reflexões, dúvidas ou mal-entendidos. A conotação (sentido figurado), quando ocorre no discurso autoritário, está sempre totalmente subordinada à intenção do emissor. Por isso, o discurso autoritário prima por uma clareza absoluta, chegando ao ponto da transparência, em que uma grande parte do discurso não é expressa concretamente pelo emissor, mas é entendida perfeitamente pelo receptor, podendo chegar a um ponto em que, dependendo do grau de autoritarismo do discurso e da distância entre emissor e receptor em termo de poder, o simples fato de proferir o discurso, ou mostrar intenção de proferi-lo, mesmo que ele não contenha em si nenhuma mensagem, gera uma compreensão imediata por parte do receptor da mensagem que lhe está sendo transmitida e da resposta que se espera dele, conforme podemos verificar abaixo:

- Anúncios de sabão em pó e detergentes-como são basicamente comprados por empregadas domésticas, muitas delas analfabetas, têm suas embalagens elaboradas de tal forma que sua marca e função são visualizadas pela forma, pelas 
cores e pela disposição dos elementos gráficos da embalagem, prescindindo quase totalmente da leitura.

- Anúncios centrados em "objetos do desejo" - muitos anúncios contêm muito poucos elementos discursivos canônicos (letras, palavras, frases, sejam escritas ou visuais), contentando-se simplesmente em apresentar um "objeto do desejo" qualquer (uma mulher bonita, um carro ou uma roupa de luxo, um tipo de vida refinado, etc.), seguido do produto ou da marca que se deseja anunciar, deixando a cargo do receptor fazer as associações necessárias. Quase que invariavelmente, esses anúncios são bem-sucedidos, por dois motivos: por um lado, embora o comando seja extremamente claro, ele não é sentido como tal pelo receptor, já que nada foi dito; por outro lado, como o comando não foi dito, torna-se mais difícil negá-lo ou resistir-lhe. Além disso, como as associações passam a ser incumbência do receptor, pode-se praticamente vincular qualquer coisa ao "objeto do desejo": uma mulher bonita serve igualmente para vender roupa, carro, amortecedores, argamassa, canetas, papel de enrolar fumo, etc.; uma praia 
deserta serve tanto para vender carros, roupas, perfumes, viagens, etc., quanto para divulgar um partido político, uma empresa educacional, um canal de televisão, etc.

- "Aquele" olhar ou "aquele" tom de voz dos pais - o primeiro exemplo da transparência total do discurso autoritário, em que a simples preparação para o discurso ou sua modulação são suficientes para veicular toda a mensagem, de maneira cabal e inequívoca, pode ser encontrado no nosso dia-a-dia, nas relações pais-e-filhos, em que o simples olhar (percepção visual) ou tom de voz (percepção auditiva) da mãe ou do pai já faz os filhos (ao menos, os filhos espertos) pararem o que estão fazendo de errado ou prepararem-se para alguma coisa boa (um presente, um passeio, uma brincadeira) que virá.

- A relação diáfana entre chefe e subordinado - um outro exemplo da transparência total (ou quase) do discurso autoritário pode ser encontrado nas relações chefe-subordinado e patrão-empregado, em que os papéis de cada um estão de tal modo estabelecidos no discurso autoritário que ele bem podia ser omitido. O simples fato de um subordinado ser chamado 
ao gabinete do chefe, na maioria das situações, já implica uma sanção qualquer. Numa situação de poder absoluto, gerando um discurso extremamente autoritário, o chefe simplesmente poderia dizer para o subordinado algo como: - Você sabe por que está aqui, não?, ou - O senhor virá buscar seus pertences amanhã?, que seria imediatamente compreendido, sem nenhum espanto ou dúvida, uma vez que quanto maior for o autoritarismo do discurso tanto mais transparente ele será.

b) Distanciamento do discurso - como o sujeito falante no discurso autoritário é exclusivo, ou seja, ele não está realmente falando para o ouvinte, mas sim dando uma ordem, um comando, para o qual ele não espera e nem admite resposta, o texto em si, o enunciado do discurso, deixa de ter importância, visto que o emissor prescinde da mensagem, ou só a valoriza na medida em que ela lhe permite alcançar seus objetivos persuasivos: induzir a venda de um produto ou a adesão a uma ideologia. O discurso autoritário é marcado por uma espécie de "desaparecimento" dos referentes (elementos norteadores do discurso), de distanciamento do emissor em relação ao discurso, de "apagamento" do conteúdo propriamente linguístico do discurso, visto 
que "a voz do enunciador é mais forte do que os próprios elementos enunciados" (CITELLI, 2001, p.40). Resumindo, pode-se dizer que o discurso autoritário descarta, de uma certa forma, os elementos do discurso: mensagem, referentes, significação, conteúdo linguístico, relação emissor-receptor, mantendo deles apenas o que serve para a persuasão, para a consecução de seus objetivos, como podemos verificar abaixo:

- Anúncios "quebrados" - vemos um anúncio que parece apontar em uma direção e finaliza indo numa direção totalmente inesperada, como os anúncios de uma campanha de bebida: "Deu duro, tome um Dreher: desce macio e reanima", em que aparecem homens superando vários tipos de dificuldades e, quando se espera que venha um produto relacionado à cena descrita, vem o slogan acima; ou o anúncio que começa como uma pesquisa sobre as diferenças e especificidades de homens e mulheres para terminar como um anúncio de sabonete; ou anúncios que começam com uma aula de português para terminar como um anúncio de antiácido ou de lanchonete.

- Anúncios "loucos" - apresenta-se uma cena ou situação empolgante, que gera uma determinada 
expectativa, para em seguida finalizar o anúncio com uma fala ou situação sem vinculação com a cena ou situação anterior, como é o caso da reprodução de uma cena nitidamente baseada no filme Brokeback Mountain (sobre uma paixão homossexual) para terminar com o anúncio de um cartão de crédito; do anúncio em que um estereótipo de professor (chato e ridículo) fala dos malefícios de beber um certo guaraná, para terminar dando um gritinho e aderindo ao guaraná; ou ainda do anúncio de uma cerveja, em que um homem "tudo de ruim": feio, baixinho, barrigudo, meio velhusco, com jeito de pobre, cafajeste e nordestino (note-se o preconceito na criação do estereótipo), vê passar uma mulher bonita e começa a gritar alvarmente: - Será?! Será?! Será?!, seguindo-se o nome da cerveja.

c) Elaboração de mitos - podemos definir um mito como uma sequência de estereótipos encadeados ou como um superestereótipo. Neste contexto, constrói-se um discurso persuasivo em que várias imagens (metáforas, metonímias, exemplos, etc.) repetem e reforçam uma visão idealizada, fantasiosa e muitas vezes preconceituosa da realidade, como podemos constatar abaixo: 
- Mito da beleza - atualmente a indústria dos cosméticos e a indústria da moda geraram um mito da beleza absolutamente irreal, em que a maioria das mulheres está empenhada: alcançar e manter por toda a vida uma magreza esguia que é apanágio de poucas adolescentes; manterse constantemente no compasso da moda, o que é praticamente impossível para quem não é milionário; conservar-se para sempre com uma aparência jovem, muito jovem. Como tais objetivos são virtualmente inalcançáveis, muitas mulheres vivem fazendo dietas e se culpando por não atingirem uma magreza quase de inanição (ou atingindo, o que é ainda pior); vivem comprando roupas e se endividando por causa disso; e vivem fazendo plásticas que, em seus estados mais perniciosos, transformam as mulheres em múmias vivas, esticadas ao ponto de não conseguirem fechar os olhos para dormir.

- Mito da raça superior - muito bem utilizado por Adolf Hitler e pelo partido nazista, afirmava serem os arianos (brancos europeus) uma raça superior às outras, as quais em consequência deveriam servi-los. Divulgado num tempo em que os alemães tinham bem poucos motivos para 
se orgulhar, tendo sido derrotados na 1a Guerra e vivendo um período de pobreza, corrupção e decadência (em Berlim, praticamente um terço das crianças eram prostituídas; a inflação alemã entrou para a história da economia como a maior que jamais se viu; os parlamentares alemães eram tão ou mais corruptos que os parlamentares brasileiros atuais), a ideia de serem superiores foi prontamente encampada pelo povo alemão, com as consequências que conhecemos. Até hoje, muitos movimentos políticos acreditam no mito da raça superior, como é o caso dos judeus sionistas (que se acreditam um povo eleito por Deus), dos membros da Ku-klux-klan e de movimentos negros radicais (que inverteram 0 mito, acreditando-se superiores aos brancos).

- Mito do PT - um mito altamente divulgado e também altamente pernicioso, confere a um simples partido um poder quase divino, na medida em que parte do pressuposto de que tudo que o Partido dos Trabalhadores ou um político do Partido dos Trabalhadores (ou a Esquerda como um todo) faz ou diz é automaticamente certo e valoroso e, em contrapartida, que tudo o que qualquer pessoa que não defende o Partido dos 
Trabalhadores (ou a Esquerda como um todo) faz ou diz é automaticamente errado e sem valor. Mesmo com as inúmeras evidências dos grandes e graves erros que membros do PT cometeram, inclusive gerando o encarceramento, após decisão judicial, de vários deles, os "crentes" do mito do PT (de acordo com Arnaldo Jabor, "o PT é a Igreja Universal da classe média") continuam inamovíveis em suas convicções.

d) Criação de inimigos - um determinado produto, partido político ou ideologia passa a apresentar o produto do concorrente ou os outros partidos políticos ou ideologias distintas como inimigos, dispostos a nos fazer todo mal e a nos destruir, razão pela qual devemos comprar um certo produto, ou votar num determinado partido, ou adotar a referida ideologia, caso contrário estaremos sozinhos contra um inimigo perigoso e fortíssimo. Estratégia altamente elaborada, com emprego esporádico na publicidade, mas que constitui uma das ferramentas mais frequentes e poderosas na propaganda política e ideológica, como é evidenciado pelos exemplos abaixo:

- Anúncio do refrigerante Dolly - através de intensa propaganda, ofabricante dos refrigerantes Dolly divulgou que estava sendo perseguido pela 
Coca-Cola, através de uma série de estratagemas que impediam a livre concorrência, fundamental para um estado democrático. Independente da veracidade das acusações, elas constituíam uma excelente peça publicitária, visto tornarem a Coca-Cola uma inimiga do livre comércio e do produto genuinamente brasileiro, que deveria ser boicotada, e a melhor forma de boicotá-la era pararmos de comprar Coca-Cola e passarmos a comprar o refrigerante Dolly.

- A campanha do judeu imundo - Joseph Goebbels, ministro de Propaganda de Hitler, aproveitou-se do antissemitismo vigente na Europa para eleger seu inimigo, causador de todas as mazelas da Alemanha e do mundo, que deveria ser combatido sem piedade. Para tanto, os alemães deveriam obedecer cegamente a Adolf Hitler, que os livraria dessa praga que os explorava economicamente (aproveitando a coincidência de os judeus serem um povo de comerciantes) e os traíra, junto com os comunistas, fazendoos perder a 1a Guerra Mundial (boato espalhado na época da rendição e que os nazistas faziam questão de confirmar). Temerosos deste inimigo terrível e insidioso, que se escondia nos próprios 
lares alemães, o povo alemão progressivamente foi aderindo à causa nazista e ao seu ideário de ódio.

- A obsessão antiamericana - os ditadores sanguinários do 30 mundo e os potentados árabes escravocratas e sexistas (em muitos países muçulmanos e africanos, a extirpação do clitóris das meninas é prática comum) têm apenas duas coisas a atormentá-los: em primeiro lugar, o fato de os países europeus e os Estados Unidos, apesar de serem democracias, serem imensamente mais ricos do que eles; em segundo lugar, o fato de os Estados Unidos (frequentemente) e alguns países europeus (de vez em quando) impedirem suas roubalheiras e massacres. O meio mais eficaz que estes países encontraram de garantir a continuidade de seus privilégios e de seus crimes foi transformar os Estados Unidos no grande inimigo, no grande Satã, de forma a minar sua capacidade de intervir em favor de alguma minoria ou alguma outra nação a quem eles estivessem dizimando, gerando a obsessão antiamericana presente em praticamente qualquer discurso da juventude ou de intelectuais iludidos e manipulados, a chorarem consternados 
pelos poucos prisioneiros humilhados na prisão de Abu-Graib da dominação americana, embora nunca tenham reclamado pelas centenas, talvez milhares de prisioneiros mutilados e assassinados em Abu-Graib ao tempo de Saddam Hussein.

e) Qualificação excludente - consiste em enfatizar e supervalorizar os valores do seu produto, partido ou ideologia e ignorar ou desvalorizar as qualidades do produto, partido ou ideologia concorrente, ao mesmo tempo em que realça e superlativa as falhas do produto, partido ou ideologia concorrente e descarta ou minimiza os defeitos do seu produto, partido ou ideologia (em casos extremos de manipulação absolutamente criminosa, os militantes são orientados até a atribuírem aos opositores os erros e atrocidades cometidos pela própria facção e, por outro lado, a se vangloriarem das glórias e acertos da facção contrária). Esse tipo de qualificação excludente, em que se exclui as qualidades de um determinado elemento para realçar as do outro, é muito usada na propaganda política e nas relações trabalhistas, como podemos ver abaixo:

- A propaganda dos candidatos majoritários - invariavelmente, um candidato a prefeito, governador ou presidente suprime e condena qualquer feito de seu oponente ou de seus 
acólitos, ao mesmo tempo em que transforma qualquer ninharia feita por um de seus colaboradores numa obra de grande envergadura e valor social.

- A assimetria das relações chefe-subordinado foi constatado que a maior causa de ineficiência e insatisfação no emprego na França (situação que se repete no Brasil) era o fato de um superior hierárquico, confrontado com dois funcionários de desempenho equivalente, elogiar e beneficiar apenas um deles, ignorando e até repreendendo o outro, o que constitui um dos exemplos mais cruéis e vulgares da qualificação excludente.

- As panelinhas intelectuais - no âmbito do trabalho intelectual, é comum determinados grupos recomendarem, premiarem, publicarem apenas os artigos, ensaios e monografias dos estudantes, professores e cientistas mais chegados, independentemente da sua qualidade, enquanto outros estudiosos e pesquisadores ficam relegados a segundo plano, sem jamais serem aclamados, publicados e, nos casos mais sombrios, empregados, não importando a qualidade de sua produção intelectual e científica. 
f) Falso debate - estratégia persuasiva que consiste em pretensamente promover um debate, só que apenas os que comungam das mesmas ideias são chamados, o que torna o que seria um debate praticamente numa lavagem cerebral. Muito usado tanto na publicidade quanto na propaganda, como podemos verificar abaixo:

- Anúncios com pesquisa de opinião - na verdade, não temos uma pesquisa de opinião, mas uma reiteração da mesma opinião através de várias vozes ou de maneiras, como acontece nos reclames de saponáceos, de produtos dietéticos e, recentemente, de produtos culturais.

- Debates políticos em universidades de maneira geral, os debates políticos são manipulados, mas aqueles que ocorrem no ambiente universitário são especialmente dignos de menção, pois sua tendenciosidade é tão evidente que se admira que alguém realmente os leve a sério, como é o caso de um debate político em que representantes do PT, PCdoB, PSTU e outros partidos de esquerda reuniram-se para debater os governos Temer e Bolsonaro e (pasmem!) ninguém achou nenhuma qualidade nos referidos governos. 
g) Inintelegibilidade aclamada - uma estratégia do discurso autoritário destinada a manter e reforçar a estrutura do poder consiste em deliberadamente criar um discurso ininteligível, mas mesmo assim aclamado, de forma a garantir que apenas uma minoria escolhida seja detentora permanentemente do direito à fala, reservando aos demais o papel de simples receptores de um discurso incompreensível, que eles são incapazes de produzir, mas que é altamente valorizado pela elite no poder, propiciando e impedindo a inserção social. São exemplos dessa estratégia qualquer livro, texto ou palestra em que se empregam termos ou construções herméticas sem a necessária explanação de seu sentido, o que dotaria alguém (o falante ou a pessoa a quem o falante está determinado a beneficiar) da exclusividade do discurso, visto ser o único capaz de realmente entender e explicar o que está sendo dito. Também são exemplos dessa estratégia toda obra de arte que necessita ser explicada por um especialista, como uma série de quadros em branco ou pintados com uma única cor, ou algumas obras de Marcel Duchamp, ou "obras de arte" que mais parecem um amontoado de lixo ou de coisas aleatórias, nas quais os "críticos de arte" descobrem significados jamais suspeitados, que só eles veem (uma roupa nova do Imperador travestida como a roupa nova do Intelectual). 
h) Deslocamento tópico - consiste em recusar-se a falar de qualquer tópico ou assunto, ignorando-o e falando sobre outra coisa, de modo a evitar responder uma questão potencialmente danosa ou desviar a atenção do interlocutor de aspectos não concernentes à persuasão ou que a dificultaria, como podemos observar abaixo:

- Anúncios com ênfase nos preços e na facilidade de pagamento - existem produtos de tão baixa qualidade, como móveis de papelão prensado, sabões que não fazem espuma, papéis higiênicos com restos sólidos na sua composição, que não há como enaltecer suas características, restando ao pobre publicitário um único recurso: desviar o assunto, falando do preço baixo, das facilidades de pagamento, dos vários modelos, etc.

- Discurso jurídico da defensoria - existem criminosos tão empedernidos que não há como defendê-los, pois são culpados de crimes hediondos e merecem o pior, mas advogados de defesa chicaneiros querem ganhar seu dinheiro e, para tanto, recorrem aos mais variados recursos para desviar a atenção do juiz e dos jurados dos crimes que o réu efetivamente praticou, quer apelando para a emoção, para a infância 
infeliz, para a carência de afeto ou econômica; quer impetrando recursos e "habeas-corpus" seguidos, tentando vencer pelo cansaço; quer através de outros artifícios para burlar a lei.

- Propaganda política - questionado sobre algo que devia ter feito e não fez, ou sobre evidências de corrupção no seu mandato, o político ou candidato procura desconversar, falar de outras coisas, atacar o candidato adversário ou o político que $\mathrm{o}$ antecedeu, chegando a partir para a ofensa e a violência ou, os mais místicos, a apelar para a religião, ou ainda, como aconteceu com um exgovernador do Rio de Janeiro, mais tarde preso por corrupção, para a greve-de-fome.

i) Guerra assimétrica - A forma mais pérfida e maliciosa de persuasão é aquilo que os estrategistas militares chamam de guerra assimétrica, uma tática de guerra em que o lado mais fraco abre o conflito de uma maneira traiçoeira e inescapável, de modo a forçar o lado mais forte a retaliar. Após isto, ele manipula a opinião pública, capitalizando sua compaixão e fazendo-a intervir a seu favor, impedindo o lado mais forte de vencer a guerra e, a longo prazo, levando-o à derrota, por exaustão ou por submissão à opinião pública. 
Essa estratégia, embora sofisticada, não requer grande aparato, podendo ser utilizada em qualquer tipo de disputa, como podemos ver nos exemplos abaixo:

- Perseguição prévia - que tanto pode ser empregada por um aluno dentro do âmbito escolar quanto por um empregado nas suas relações trabalhistas, consiste na declaração pelo estudante ou pelo empregado de que está sendo perseguido pelo professor ou pelo chefe ou empregador. Mesmo que não seja verdade, que estejamos diante apenas de um aluno que não se esforça ou de um empregado incompetente, tudo que o professor fizer contra o aluno ou que o chefe fizer contra ao empregado, ainda que seja justo (tomar uma prova porque o aluno está colando, reclamar do atraso do empregado, etc.) passará a ser visto como uma confirmação das acusações previamente feitas pelo "pobre" estudante ou funcionário. O filme Olleana, de David Mamet, baseado em fatos ocorridos numa escola secundária da Austrália, narra brilhantemente esta estratégia de manipulação da opinião no âmbito escolar.

- Proclamação de preconceito - qualquer membro de uma minoria (negros, gays, 
deficientes, etc.) pode valer-se deste artifício da guerra assimétrica: quando confrontado com uma crítica ou punição, justa ou injusta, afirmase estar sendo vítima de preconceito, o que faz com que o lado rival tenha que se defender, às vezes legalmente, o que esvazia sobremaneira a força de sua crítica ou a extensão de sua punição. Recentemente o presidente Bolsonaro denunciou com provas essa manipulação, ao mostrar fotos, tiradas durante a Passeata do Orgulho Gay, em que homossexuais perpetravam atos horrivelmente obscenos diante da população, sendo eles, suposta minoria perseguida, os agressores e não as vítimas. Mesmo assim, essa demonstração de guerra assimétrica foi bastante bem-sucedida, com milhares de pessoas condenando a atitude do nosso presidente, afirmando ser Bolsonaro o obsceno por mostrar as cenas de sexo explícito em público, e não os homossexuais por fazer tais cenas.

- Ataque do mais fraco contra o mais forte mesmo sabendo que não pode ganhar, o lado mais fraco de um conflito ataca, sabendo que a opinião pública praticamente ignorará seu ataque, mas que se acirrará contra o outro lado, 
quando este retaliar, com um poder destrutivo muito maior. Podemos ver esta estratégia tanto em dimensões mínimas, como no filho caçula que bate no irmão maior e mais forte, contando com a proteção da mãe, que não deixará que ele se machuque, até chegar ao acontecimento mais importante do século XXI: os atentados de 11 de setembro de 2001, em que determinados grupos árabes fizeram um ataque homicida covarde contra civis americanos, contando com o fato de que a mídia, contaminada pelo ideário esquerdista e pela obsessão antiamericana, praticamente ignoraria este crime nefando, mas reagiria veementemente contra a justa reação americana, baseada no direito inalienável de qualquer nação à autodefesa, como de fato ocorreu.

\section{REFERÊNCIAS}

CITELLI, Adilson (2001). Linguagem e persuasão. São Paulo: Ática.

Afrânio da Silva Garcia concluiu o doutorado em Letras (Letras Vernáculas) pela Universidade Federal do Rio de Janeiro (UFRJ) em 1996. Atualmente é professor adjunto da Universidade do Estado do Rio de Janeiro (UERJ). Publicou 72 artigos em periódicos especializados e 43 trabalhos em anais de eventos. Possui nove livros publicados. Participou de 43 eventos no Brasil e no exterior. Recebeu dois prêmios e/ou homenagens. Organizou 12 eventos, sendo um de caráter internacional. 
Atua na área de Letras, com ênfase em Semântica. Em seu currículo Lattes os termos mais frequentes na contextualização da produção científica, tecnológica e artístico-cultural são: Língua Portuguesa, Semântica, Estilística, Especialização, Interpretação, Retórica, Ensino, Semiologia, Sintaxe e Figuras de linguagem. Participou recentemente de oito eventos internacionais: na China, em Portugal, na Itália, na França e nos Estados Unidos. Neste último, teve quatro trabalhos publicados. 